\title{
Mutual Fund Tournaments: Evidence From Global And International Funds
}

Michael R. Melton, (E-mail: mmelton@rwu.edu), Roger Williams University Thomas S. Zorn, (E-mail: tzorn@unl.edu), University of Nebraska-Lincoln Richard A. DeFusco, (E-mail: rdefusco@unl.edu), University of Nebraska-Lincoln

\begin{abstract}
For a sample of global and international equity mutual funds, we test the proposition that managers likely to end up as "losers" manipulate fund risk differently from interim winners. In contrast with Brown, Harlow, and Starks (1996) who found robust support for the tournament model, we found no evidence of tournament like behavior for international and global mutual funds. A possible explanation of this behavior is that investors in these funds are primarily seeking diversification and therefore are less sensitive to relative performance.
\end{abstract}

\section{Introduction}

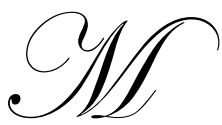

utual funds provide individual investors with a cost-effective means of diversifying. Some researchers contend that investment managers' contracts create potential agency problems (e.g., Golec (1992) and Starks (1987)). For instance, almost all funds have asset-based fees, whereby the investment manager is compensated (via a prescribed declining schedule) based on the total assets under management. In addition to the asset-based fee, some funds also employ performance incentive fees. With either type of compensation contract, fund manager actions that may be beneficial to the investment manager, may not always benefit fund shareholders. Brown, Harlow, and Starks (BHS; 1996) study provides an interesting result that views investment managers' compensation contracts from a different perspective. Over the period 1976 to 1991 they find that the managers of mutual funds categorized as growth oriented likely to end up as "losers" tend to increase fund volatility to a greater extent than mid-year winners. The effect became stronger as the mutual fund industry grew and investor awareness of fund performance increased over time. ${ }^{1}$

BHS's findings are consistent with the notion that managers perceive the mutual fund industry as a tournament. Fund mangers attempt to maximize their expected compensation by revising the composition of their portfolios depending on their relative performance during the year. Results by Sirri and Tufano (1998) show that investors respond to relative rankings. Specifically, they find managers who earn relatively higher returns receive larger proportional inflows while mangers that earn poorer returns are not penalized in an offsetting manner. Inflows cause fund manager compensation to increase due to the presence of asset based fees. Added risk taking by "losers" resulting in poor performance does not affect manager compensation as adversely. Thus, decisions made by fund managers are predicated on a call option-like payoff that is influenced by their relative performance ranking.

In contradiction to the BHS finding, Busse (2000), using daily return data, found no evidence in support of the tournament hypothesis. Busse argues that daily return data provide a more efficient estimate of fund volatility. Busse's sample consisted of 230 domestic equity funds with a sample period of 1985 to 1995.

\footnotetext{
${ }^{1}$ Today, investors have access to mutual fund rankings through a number of publications including Forbes, Money, Consumer Reports and Kiplingers Personal Finance, to name a few. A few examples of Internet web sites devoted to such rankings include Standard and Poor's, Morningstar, and Kiplinger Fund Center.
} 
BHS and Sirri and Tufano used funds categorized as growth oriented for analysis. Busse also used fund categories consistent with that objective. As stated in BHS, the main reasons for using growth funds is that they typically receive the largest attention by press and investors alike, and are the most widely followed and often ranked-class of funds. Such funds fit the qualitative criteria of the tournament model. In addition, McDonald (1974) notes that this category of funds is likely to have a greater risk taking, consistent with the tournament model.

In recent years, funds other than growth funds have certainly received attention from both investors and press. No study to date has investigated whether tournament like behavior exists in other segments of the mutual fund industry. Funds with objectives other than growth may or may not have wide discretion in altering the interim risk of their portfolios. The ability to alter risk relative to those following the same objective would influence the likelihood of observing tournament-like behavior. Some funds with broad objectives such as international or global have a wide array of assets from which to choose, presumably making it easier to diversify or to alter risks. In this paper we test the tournament hypothesis for funds with objectives other than growth in order to determine if the results found by BHS can be generalized to other segments of the mutual fund industry.

Today, U.S. investors can access foreign markets via mutual funds with two broad objectives: global (U.S. equities can be included) and international (no U.S. equities). As of year end 1997, there were 673 international equity funds with total investment of $\$ 186$ billion, and 274 global equity funds with total investment of $\$ 132$ billion. It would not be surprising that given the large array of assets, and given BHS's finding, tournament-like behavior exists in the case of global and international funds.

In this paper, we test the tournament hypothesis to funds with a broad objective of global equity or international equity. Additionally, we look at two specialized subsets of funds that are classified as global-growth and international-growth. These latter funds provide us with a sample that is parallel to BHS's sample of growthoriented funds. In contrast to BHS who found strong support for the tournament model, we did not find support for the tournament model in our sample.

Growth funds may be particularly sensitive to performance because their investors are clearly concerned with performance. Investors in these funds may be sensitive to performance of a given fund relative to other funds or an index. In contrast, for investors in international and global funds, the diversification motive may be more important. International fund investors may be relatively sensitive to risk. It may be possible that investors in Global and International funds may be less sensitive to ordinal ranking.

The next section introduces the methodology and data while Section 3 describes the empirical findings. Section 4 summarizes and concludes the paper.

\section{Methodology and Data}

Monthly return data for a sample of funds with broad objectives of Global equity and International equity were collected from the mutual fund database maintained by Alexander Steele's Mutual Fund Expert. The original data in this database is provided by Standard \& Poors Micropal. Monthly return data on the Steele database covers the 10-year period June 1988 to May 1998. In order for a fund to enter any year's tournament, it must have complete return data for that year.

Our sample begins with full year data starting in calendar year 1989 and ending in calendar year 1997. Tables 1 and 2 provide relevant aspects of the sample of global and international funds. In each table we provide summary data on the number of firms with complete return data in each year, the total dollar investment, the median annual return, and the median monthly standard deviation. For global funds (Table 1) the number of funds rose from 33 in 1989 to 274 by year-end 1997 and Global-growth grew from 33 funds to 141.

Median annual return for global funds is volatile from year to year, ranging from a high of $29.31 \%$ (1993) to a low of $-0.91 \%$ (1990). Global-growth also shows significant variation in year-to-year median annual return, ranging from a low of -9.35 to a high of 31.17 percent. For International funds (Table 2) we also see a significant 
increase in the number of funds over the sample period: the sample has 58 funds in 1989 and 637 in 1997. International-growth funds grew from 24 funds to 232 .

\subsection{BHS's Tournament Model}

To test whether the tournament-like behavior holds for our sample of funds, this study follows the methodology set forth by BHS. We test the proposition that funds which perform poorly during the first few months of a particular year (i.e., losers) increase their total risk during the rest of the year relative to funds that perform well during the first period (winners). Initially, we test whether,

$$
\left(\frac{\sigma_{2 L}}{\sigma_{1 L}}\right)>\left(\frac{\sigma_{2 W}}{\sigma_{1 W}}\right),
$$

where,

$\sigma_{\mathrm{tL}}$ is the volatility of loser funds during time period $t$, and

$\sigma_{\mathrm{tW}}$ is the volatility of winner funds during time period $t$.

Winning (losing) funds are defined in two ways: funds that outperform (underperform) the median fund during the period of evaluation, or funds that are in the top (bottom) quartile of all funds during the period of evaluation.

return,

For fund $j$, performance during the year $y$ evaluation period is computed as the total compounded total

$$
R T N_{j M y}=\prod_{m=1}^{M}\left(1+r_{j y m}\right)-1,
$$

where,

$r_{j y m}$ is the monthly return for fund $j$ during month $m$ during year $y$, and there are $M$ monthly returns during the year $y$ evaluation period. As in BHS, the evaluation period is separated from the latter part of the year at five different break points: April, May, June, July, and August.

For each fund $j$, the standard deviation ratios in equation (1) are computed as follows:

$$
R A R_{j y}=\left[\frac{\frac{1}{(12-M)-1} \sum_{m=M+1}^{12}\left(r_{j y m}-\bar{r}_{j y(12-M)}\right)^{2}}{\frac{1}{M-1} \sum_{m=1}^{M}\left(r_{j y m}-\bar{r}_{j y M}\right)^{2}}\right]^{\frac{1}{2}}
$$

where there are $M$ trading months during the evaluation period. The prediction of the tournament model is that the "risk adjustment ratio" described by equation 3 should be significantly larger for funds labeled as losers at month $M$ than for those designated as winners.

With these definitions a $(R T N, R A R)$ pair for every fund in each of the annual tournaments is computed. The basic test procedure is to generate a $2 X 2$ contingency table in which each pairing is placed into one of four cells: high $R T N$ (i.e., winner) / high RAR; low RTN (i.e., loser) / high RAR; high RTN / low RAR; low RTN / low $R A R$. The null hypothesis is that the percentage of the sample falling into each of the four cells is equal (i.e., $25 \%$ ). The alternative hypothesis consistent with the tournament hypothesis is that the low $R T N$ / high RAR and high RTN / 
low $R A R$ cells have a frequency significantly larger than 25 percent. Significance tests are conducted using a chisquare statistic having one degree of freedom. As in BHS, tests are conducted with and without the month of December to avoid potential problems due to window dressing.

Following BHS, a second proposition concerning the various demographic characteristics of the funds is tested. BHS contend that the size and age of the fund affects a manager's willingness or ability to alter a portfolio's investment characteristics. BHS hypothesize that when a large-fund manager is an interim loser he or she may not be able to alter risk in a timely fashion due to a number of clientele and liquidity reasons. Managers of smaller, newer funds may not be similarly constrained. In addition, smaller, newer funds may be forced to pursue new investments more aggressively than larger funds in order to survive. Finally, investors are more likely to be influenced by poor short-term performance for a newer fund than for an older fund with a proven track record. Managers of newer funds may therefore take on a more aggressive approach to reversing mid-tournament losses. We test whether Equation 1 is more likely to hold for small, new funds in comparison to large, well-entrenched funds.

We also examine whether the extent of time a manager manages a particular fund in any way impacts risktaking strategies. Managers of new funds may be motivated to take a more aggressive approach to reversing midtournament losses. Conversely, we hypothesize that managers with longer tenure (entrenchment) can take a more aggressive approach in reversing mid-tournament losses without the threat of termination.

One final test using BHS's medology assesses whether the size of a fund's cash flow affects risk taking. Sirri and Tufano's results indicate that investors respond to fund rankings. Funds that earn relatively higher returns receive larger proportional inflows while funds that earn relatively lower returns are not penalized in an offsetting manner. Within the tournament framework, fund managers' asset based compensation should make the marginal benefit to increasing risk greater than the consequences if the fund becomes a poor performer. Because decisions made by fund managers are predicated on a call option-like payoff that is influenced by their relative performance ranking, funds with larger cash flows may be more prone to take risks. Those funds that typically experience a large positive cash flow relative to the size of total assets who are mid-tournament losers are more inclined to alter risk without the threat of diminishing cash flows.

\subsection{Alternative Test of the Tournament Hypothesis}

In addition to the BHS tests, we utilize OLS to examine the simultaneous effect of each variable. Specifically, we estimate

$$
\begin{aligned}
R A R_{M, 12-M}= & \alpha+\beta_{1} \text { WINLOSE }+\beta_{2} \text { GLOBINTL }+\beta_{3} \text { FUNDLIFE }+\beta_{4} \text { FUNDSIZE }+ \\
& \beta_{5} \text { MGRTEN }+\beta_{6} \text { CASHFLOW }+\beta_{7} \text { WLGLOBINTL }+\beta_{8} \text { WLFUNDLIFE }+ \\
& \beta_{9} \text { WLTENURE }+\beta_{10} \text { GIFUNDLIFE }+\beta_{11} \text { GITENURE }+\beta_{12} \text { LIFETENURE }+\varepsilon_{t}
\end{aligned}
$$

where RAR is the "risk adjustment ratio" described by equation 3. The variable definitions are in Table 3. In general, the first six variables are characteristics and the last six variables are interaction terms. The variable WINLOSE tests if funds that perform poorly during the first few months of a particular year (i.e., losers) increase their risk during the rest of the year relative to funds that perform well (winners). Besides the control variables differences in fund type, fund life, fund size, manager tenure, and fund cash flow, the winner/loser interaction terms test if increased risk taking exists for a subset of funds. 


\section{Empirical Results}

\subsection{Modifying Portfolio Risk using Assessment Periods}

This study applies the BHS methodology to Global and International equity funds. In addition, the tests were separately performed on specific objective categories, International growth and Global growth. For each separate sample a $2 \times 2$ contingency table is computed with performance assessment beginning in month $\mathrm{M}=4,5,6$, 7, and 8. For example, if $M=4$ then the assessment period that is reported would be recorded as $(4,8)$ (i.e., 4 monthly returns (Jan - April) used to compute accumulated return and 8 monthly returns (May - Dec) used to compute monthly return standard deviation). With 5 assessment periods and 4 cells, 20 combinations of $R T N / R A R$ are reported.

The chi-square statistic reported tests the null hypothesis of equal cell frequencies. The tournament hypothesis is supported only if the cells labeled low $R T N$ / high $R A R$ and high $R T N$ / low $R A R$ have frequencies larger than $25 \%$. For each separate sample, as defined by the broad objective categories and the detailed objective categories, results are presented with and without December returns and with winners/losers based on median and quartile rankings. December returns are excluded in order to avoid problems due to window dressing, whereby managers manipulate portfolios through acquisitions or liquidations at year-end for accounting or reporting purposes. Although median-based rankings allows all funds in the sample to be included, these results alone may be misleading because winner-loser distinctions in the middle of the rankings are perhaps deceptive. At the expense of losing half the available data tests based on quartile rankings isolates "extreme" winners and losers.

The results for global equity are reported in Table 4. Results for median rankings and quartile rankings are presented with all monthly returns and without December returns. Aggregated over the period 1989-1997, we have 1065 observations for median rankings and 538 for quartile rankings. The results based on median rankings show some support for tournament-like behavior for assessment period $(4,8)$ with and without December at the 5\% level of significance. All other assessment periods are not significantly different from equal cell frequencies. Results for quartile rankings only show support for the tournament model with all monthly returns for the assessment period $(4,8)$.

Because global equity may not be comprised of homogeneous detailed objectives, we also look at the results for global-growth in Table 5. The results in Table 5 are virtually identical in terms of statistical significance to those in Table 4 . Whether ranked by median or quartile performance, increased risk taking is again only present for the assessment period $(4,8)$.

Results for the international equity and international-growth are presented in Tables 6 and 7. International equity funds (median and quartile rankings) show support for the tournament model only for the assessment period $(8,4)$ with and without December returns. Results for International-growth funds, while significant for certain assessment periods with median and quartile rankings, is opposite in sign to the predictions of the tournament model. For those cases that are significant, interim losers (winners), on average, took less (more) risk.

Unlike BHS who found rather robust support for the tournament model across all assessment periods, we conclude that the evidence for behavior consistent with tournament theory on the international side of the mutual fund business is weak at best. Our results are somewhat surprising since most of the funds in our sample are newer and less well established. In addition, the BHS results suggest a more pronounced tournament effect during the last 5 years of their sample (ending in 1991), a period of more heightened awareness of fund performance on the part of investors. Our sample spanning the years 1989-1997 would appear prime for increased tournament effect. An added dimension of our sample is that fund managers have a wider array of assets from which to choose to alter risk. Even with this added degree of freedom for fund managers in terms of asset selection, strong support for tournament effects is missing. 


\subsection{Fund Life, Fund Size, Manager Life, and Cash Flow}

BHS also test if managers in newer, smaller funds have a greater incentive to change risk and may be less constrained by market forces to take action in comparison to larger, more established funds. To test this proposition each detailed objective category is segmented based on such characteristics as fund life, fund size, manager life and cash flow. In this case, we only examine the period $(5,7)$ - where the performance assessment month is July $(M=7)$. In addition, all variables are based on median ranking, excluding quarterly rankings. Once segmented by the defined characteristics, a $(R T N, R A R)$ pair for every fund in each of the annual tournaments is created. A $2 X 2$ contingency table is generated, each pairing is placed into one of four cells: high $R T N$ (i.e., winner) / high RAR; low $R T N$ (i.e., loser) / high $R A R$; high $R T N$ / low RAR; low $R T N$ / low $R A R$ is replicated. The null hypothesis is that the percentage of the sample falling into each of the four cells is equal (i.e., 25\%). The alternative hypothesis consistent with the tournament hypothesis is that the low RTN / high RAR and high $R T N$ / low RAR cells have a frequency significantly larger than 25 percent. Significance tests are conducted with a chi-square statistic having one degree of freedom.

\subsubsection{Fund Life}

To test the prediction that newer funds make larger adjustments in portfolio risk between winners and losers, the detailed objective "growth" categories of international and global equity funds are segmented on the basis of fund life. Those funds in existence prior to (after) the median existence for a particular tournament year are defined as entrenched (new) funds. Table 8, test (1a) reports results for all funds having the broad objective Global Equity, categorized by their detailed objective Global growth. The results based on median rankings are not consistent with those predicted by the tournament hypothesis. Not surprisingly, Table 8, Test (1b) details much of the same results. For International equity funds defined by the detailed objective growth, there is little evidence of tournament-like behavior. For entrenched funds, the results are opposite of what we would expect for the tournament hypothesis.

\subsubsection{Fund Size}

To test the hypothesis that smaller funds have greater incentive to change risk and may be less constrained by market forces to take action in comparison to larger, more established funds, detailed objective categories are segmented on the basis of fund size. Those funds having a greater (smaller) number of total assets than the median number for a particular tournament year are defined as large (small) funds. ${ }^{2}$ Table 8 , test (2a) reports results based on median rankings for all funds having the broad objective Global Equity categorized by their detailed objective growth. These results show little support for the tournament model, with no significance at any level. Table 8, test (2b) presents results for the comparison of small versus large funds for International funds categorized by their detailed objective growth. Results for small funds are significantly different from equal cell frequencies for International Growth and are consistent will the predictions of the tournament hypothesis.

\subsubsection{Manager's Tenure}

We also test whether the length of time a fund manager manages a particular fund (tenure) impacts his/her decision to adjust portfolio risk after the interim ranking date. It is not obvious whether new or entrenched fund managers should be willing to take on more risk. New fund managers, if they're losers, may feel greater to take on more risk. Alternatively, entrenched managers may feel secure enough to take on additional risk if they find themselves to be losers. In any event, the null hypothesis remains that the percentage of the sample falling into each of the four cells is equal (i.e., 25\%).

Table 8, test (3a) reports results for Global Equity categorized by their detailed objective, growth while test (3b) reports results for International Equity categorized by their detailed objective growth. The results for Global Equity show that entrenched losers took on more risk while new losers took on less risk. For winners, just the

\footnotetext{
${ }^{2}$ Data found Morningstar Principia Plus Mutual Fund Database (1998).
} 
opposite is true. For International Equity, entrenched managers considered to be, losers take on less risk while winners take on more risk.

\subsubsection{Size of Cash Flow}

Sirri and Tufano find mutual fund consumers chase returns, investing in funds with the highest recent returns, though failing to liquidate from poor performers. It is plausible that those funds generating smaller cash flows relative to the size of total assets, will be apt to take on greater risk in order to improve ranking, and thus, cash flow. We examine whether funds that have larger cash flow relative to their competitors increase risk.

To test the prediction that funds with smaller cash flows have greater incentive to change risk, we use a measure of net fund flows (FLOW) - net growth in fund assets beyond reinvested dividends - as derived by Sirri and Tufano.

$$
\mathrm{FLOW}_{i, t}=\frac{\left(\mathrm{TNA}_{i, t}-\mathrm{TNA}_{i, t-1}\right) \times\left(1+\mathrm{R}_{i, t}\right)}{\mathrm{TNA}_{i, t-1}}
$$

The variable $\mathrm{TNA}_{i, t}$ represents fund $i$ 's total net assets at time $t$ and $\mathrm{R}_{i, t}$ is the fund's return over the prior year. ${ }^{3}$ The measure FLOW signifies the percentage growth in a fund in excess of the growth that would have occurred had no new funds flowed in and all dividends had been reinvested. Following the format of previous tests, detailed objective categories are segmented on the basis of the size of fund flow. Those funds having a larger (smaller) flow of funds than the median number for a particular tournament year are defined as large (small) funds. Test (4a) in Table 8 reports results based on median rankings for all funds having the broad objective Global Equity categorized by their detailed objective growth. As in previous tests, these results show little support for the tournament model. Funds, whether large or small, do not differ significantly from equal cell frequencies. Table 8, test (4b) presents results comparing funds with small cash flows to funds with large cash flows for International funds categorized by their detailed objective - growth. Again, we do not observe differences from equal cell frequencies.

\subsection{Regression Test of the Tournament Hypothesis}

Table 9 presents regression results based on equation 4. We examine whether or not losers take on more risk after a specified assessment period, holding all other fund characteristics constant.

In columns 1a, 2a, 3a and 4a, winners and losers are separated based on median results. While $1 \mathrm{~b}, 2 \mathrm{~b}, 3 \mathrm{~b}$ and $4 b$ the rankings are based on quartile results. Regression results $1 b, 2 b, 3 b$, and $4 b$ exclude the interaction terms. The remaining regressions include the interaction terms. Regressions 3a through $4 \mathrm{~b}$, the December returns are excluded. The assessment period $(5,7)$ is used, following the rationale used by BHS.

The coefficient of the LOSE/WIN variable is the only one relevant to the tournament hypothesis. In none of the regressions does the variable LOSE/WIN support the tournament hypothesis. There does not appear to be a tendency for losers, in the interim period, to take on more risk for either global or international funds.

\section{Conclusions}

Considerable research has been conducted on the behavior of mutual fund risk taking. An interesting line of research concerns risk-taking behavior of fund managers. In this paper we test whether or not fund managers in the Global and International segments of the mutual fund industry behave consistent with the tournament hypothesis. That is, whether or not fund managers in Global and International fund categories revise the composition of their portfolios depending on their relative ranking during the year. Although BHS found that

\footnotetext{
${ }^{3}$ Data for total net asset values of funds were accumulated from Morningstar Principia Plus Mutual Fund Database.
} 
growth funds exhibit tournament-like behavior, it is not obvious that this applies to other fund sectors. In particular, for Global and International funds, investors may be less sensitive to performance and more interested in diversification. Busse, on the other hand, using daily data, did not find support for the tournament hypothesis for growth funds. Over our sample period 1989 to 1997, we do not find support for the tournament hypothesis.

\section{References}

1. Bronars, S., 1987, Risk Taking Behavior in Tournaments, Working paper, University of California at Santa Barbara.

2. Brown, S., W. Goetzmann, R. Ibbotson, and S. Ross, 1992, Survivorship Bias in Performance Studies, Review of Financial Studies 5, 553-580.

3. Brown, K., C., Harlow, and L. Starks, 1996, Of Tournaments and Temptations: An Analysis of Managerial Incentives in the Mutual Fund Industry, Journal of Finance, March, 85-110.

4. Ehrenberg, R. and M. Bognanno, 1990, Do Tournaments have Incentive Effects? Journal of Political Economy, 98, 1307-1324.

5. Golec, J., 1992, Empirical Tests of a Principal-Agent Model of the Investor-Investment Advisor Relationship, Journal of Financial and Quantitative Analysis, 27, 81-96.

6. Grinblatt, M., and S. Titman, 1989a, Adverse Risk Incentives and the Design of Performance-based Contracts, Management Science 35, 807-822.

7. Grinblatt, M., and S. Titman, 1989b, Portfolio Performance Evaluation: Old Issues and New Insights, Review of Financial Studies 2, 393-421.

8. Kritzman, M. 1987, Incentive Fees: Some Problems and Some Solutions, Financial Analysts Journal, 43, 21-26.

9. McDonald, J. 1974, Objectives and Performance of Mutual Funds, 1960-1969, Journal of Financial and Quantitative Analysis, 9, 311-333.

10. Sirri, E. R., and P. Tufano, 1998, Costly Search and Mutual Fund Flows, Journal of Finance, 53, 15891622.

11. Starks, L., 1987, Performance Incentive Fees: An Agency Theoretic Approach, Journal of Financial and Quantitative Analysis, 22, 17-32.

Table 1

Summary information is for the 274 (141) funds having a broad objective of Global Equity (detailed objective global growth) as reported by Alexander Steele's Mutual Fund Expert and Morningstar Mutual Fund Services. A fund is only included in an annual sample if it has return data for the entire year.

\begin{tabular}{ccccccccc}
\hline Year & \multicolumn{2}{l}{ Number of Funds } & \multicolumn{2}{c}{$\begin{array}{c}\text { Total Dollar } \\
\text { Investment (millions) }\end{array}$} & \multicolumn{2}{c}{$\begin{array}{c}\text { Median Annual } \\
\text { Return } \mathbf{~ \$ U ~ ( \% ) ~}\end{array}$} & \multicolumn{2}{c}{$\begin{array}{c}\text { Median Monthly Std. } \\
\text { Deviation (\%) }\end{array}$} \\
\hline 1989 & 33 & $(21)$ & 14,448 & $(11,178)$ & 22.60 & $(23.53)$ & 3.49 & $(3.56)$ \\
1990 & 38 & $(22)$ & 13,990 & $(10,520)$ & 0.91 & $(-9.35)$ & 5.18 & $(5.38)$ \\
1991 & 50 & $(28)$ & 20,361 & $(13,911)$ & 18.31 & $(17.09)$ & 4.05 & $(4.15)$ \\
1992 & 59 & $(35)$ & 30,988 & $(22,885)$ & 2.74 & $(1.79)$ & 2.33 & $(2.35)$ \\
1993 & 72 & $(43)$ & 41,989 & $(23,899)$ & 29.31 & $(31.17)$ & 3.30 & $(3.35)$ \\
1994 & 118 & $(95)$ & 60,427 & $(33,092)$ & -2.53 & $(-1.80)$ & 3.13 & $(3.32)$ \\
1995 & 183 & $(95)$ & 76,631 & $(41,919)$ & 16.45 & $(15.46)$ & 2.66 & $(2.75)$ \\
1996 & 238 & $(121)$ & 104,860 & $(58,398)$ & 15.41 & $(16.21)$ & 2.57 & $(2.62)$ \\
1997 & 274 & $(141)$ & 132,481 & $(79,168)$ & 11.42 & $(12.87)$ & 4.40 & $(4.47)$
\end{tabular}


Table 2

Summary information is for the 673 (232) funds having a broad objective of International Equity (detailed objective international growth) as reported by Alexander Steele's Mutual Fund Expert and Morningstar Mutual Fund Services.

A fund is only included in an annual sample if it has return data for the entire year.

\begin{tabular}{lcccccccc}
\hline Year & \multicolumn{2}{c}{$\begin{array}{c}\text { Number of } \\
\text { Funds }\end{array}$} & \multicolumn{2}{c}{$\begin{array}{c}\text { Total Dollar } \\
\text { Investment (millions) }\end{array}$} & \multicolumn{2}{c}{$\begin{array}{c}\text { Median Annual Return } \\
\text { \$US (\%) }\end{array}$} & \multicolumn{2}{c}{$\begin{array}{c}\text { Median Monthly } \\
\text { Std. Deviation (\%) }\end{array}$} \\
\hline 1989 & 58 & $(24)$ & 9,738 & $(5,293)$ & 23.01 & $(22.72)$ & 4.22 & $(3.49)$ \\
1990 & 71 & $(29)$ & 12,929 & $(6,779)$ & -11.86 & $(-9.76)$ & 6.33 & $(5.95)$ \\
1991 & 91 & $(33)$ & 17,085 & $(9,439)$ & 12.11 & $(11.81)$ & 4.07 & $(3.35)$ \\
1992 & 121 & $(48)$ & 21,496 & $(12,629)$ & -3.47 & $(-3.45)$ & 3.25 & $(2.47)$ \\
1993 & 173 & $(76)$ & 62,493 & $(32,738)$ & 36.05 & $(35.79)$ & 4.15 & $(4.63)$ \\
1994 & 247 & $(104)$ & 91,913 & $(50,789)$ & -1.10 & $(0.01)$ & 3.73 & $(5.64)$ \\
1995 & 408 & $(153)$ & 109,254 & $(64,813)$ & 7.61 & $(10.67)$ & 3.28 & $(4.61)$ \\
1996 & 534 & $(196)$ & 161,952 & $(97,010)$ & 11.76 & $(11.18)$ & 2.46 & $(3.65)$ \\
1997 & 673 & $(232)$ & 186,626 & $(118,253)$ & 2.33 & $(5.12)$ & 4.90 & $(7.06)$
\end{tabular}

Table 3

Variables for the Single-Equation (Small) and (Large) OLS Model

\begin{tabular}{l}
\hline Variable Name \\
\hline WINLOSE \\
GLOBINTL \\
FUNDLIFE \\
FUNDSIZE \\
MGRTEN \\
CASHFLOW \\
WL/GI \\
WL/FUNDLIFE \\
WL/TENURE \\
GI/FUNDLIFE \\
GI/TENURE \\
LIFE/TENURE
\end{tabular}
Description

1 if Fund is defined as winner $(R T N)$ for the interim assessment date: $M=5$, zero otherwise

1 if Fund is defined as Global Equity, zero if defined as International Equity

1 if Fund has a life greater than the median life of the sample, zero otherwise

Fund size defined as net assets (in millions)

1 if Fund has a manager tenure greater than the median tenure of managers in the sample, zero otherwise

Net fund flows (FLOW) - net growth in fund assets beyond reinvested dividends as derived by Sirri and Tufano (Equation 4)

Cross product of dummies WINLOSE and GLOBINTL

Cross product of WINLOSE and FUNDLIFE

Cross product of WINLOSE and MGRTEN

Cross product of GLOBINTL and FUNDLIFE

Cross product of GLOBINTL and MGRTEN

Cross product of FUNDLIFE and MGRTEN

\section{Table 4}

Data for the classifications is constructed on a yearly basis from monthly returns of 274 funds having a broad objective of Global Equity, and aggregated for the sample period 1989 - 1997. Cell frequencies are reported for a 2 X 2 classification scheme involving the rank-ordered variables: (i) the Risk Adjustment Ratio (RAR); and (ii) the compound total return through the first $M$ months of the year $(R T N)$. Five different values are given for the interim assessment dates: $M=4,5,6,7$ and $8 . R A R$ is the ratio of the standard deviations measured before and after month $M$. Funds are divided into four groups on a yearly basis according to (i) whether $R T N$ is below ("low" or "loser") or above ("high" or "winner") the median or in the highest ("winner") or lowest ("loser") quartile, and (ii) whether $R A R$ is above ("high") or below ("low") the median. Included are results for $R A R$ rankings calculated both with and without December returns. 
Sample frequency (\% of Observations)

\begin{tabular}{|c|c|c|c|c|c|c|c|c|c|}
\hline & & & & & $\begin{array}{l}R T N \\
\text { ers") }\end{array}$ & $\begin{array}{l}\text { High } \\
\text { ("Win }\end{array}$ & $\begin{array}{l}T N \\
\text { ers") }\end{array}$ & & \\
\hline Ranking & Returns & $\begin{array}{l}\text { Assessment } \\
\text { Period }\end{array}$ & Observations & $\begin{array}{l}\text { "Low" } \\
\text { RAR }\end{array}$ & $\begin{array}{l}\text { "High" } \\
\text { RAR }\end{array}$ & $\begin{array}{l}\text { "Low" } \\
\text { RAR }\end{array}$ & $\begin{array}{l}\text { "High" } \\
\text { RAR }\end{array}$ & $\chi^{2}$ & $\begin{array}{c}\rho- \\
\text { value }^{4}\end{array}$ \\
\hline Median & All Monthly & $(4,8)$ & 1065 & 22.4 & 27.7 & 27.7 & 22.2 & $\begin{array}{l}12.43 \\
5\end{array}$ & 0.000 \\
\hline & & $(5,7)$ & & 23.7 & 26.5 & 26.5 & 23.4 & 3.744 & 0.053 \\
\hline & & $(6,6)$ & & 24.8 & 25.4 & 25.4 & 24.5 & 0.228 & 0.633 \\
\hline & & $(7,5)$ & & 25.7 & 24.4 & 24.4 & 25.4 & 0.604 & 0.437 \\
\hline & & $(8,4)$ & & 25.1 & 25.1 & 25.1 & 24.8 & 0.025 & 0.873 \\
\hline Median & December & & & & & & & & \\
\hline & Excluded & $(4,8)$ & 1065 & 23.6 & 26.6 & 26.6 & 23.3 & 4.232 & 0.040 \\
\hline & & $(5,7)$ & & 24.5 & 25.6 & 25.6 & 24.2 & 0.701 & 0.402 \\
\hline & & $(6,6)$ & & 24.9 & 25.3 & 25.3 & 24.6 & 0.131 & 0.718 \\
\hline & & $(7,5)$ & & 25.3 & 24.9 & 24.9 & 25.0 & 0.040 & 0.841 \\
\hline & & $(8,4)$ & & 25.0 & 25.2 & 25.2 & 24.7 & 0.063 & 0.802 \\
\hline Quartile & All Monthly & $(4,8)$ & 538 & 24.0 & 26.0 & 31.0 & 19.0 & $\begin{array}{l}16.15 \\
6\end{array}$ & 0.000 \\
\hline & & $(5,7)$ & & 26.8 & 23.2 & 28.4 & 21.6 & 6.431 & 0.011 \\
\hline & & $(6,6)$ & & 27.5 & 22.5 & 27.0 & 23.0 & 4.349 & 0.037 \\
\hline & & $(7,5)$ & & 28.1 & 21.9 & 26.0 & 24.0 & 4.498 & 0.034 \\
\hline & & $(8,4)$ & & 27.7 & 22.3 & 28.6 & 21.4 & 8.781 & 0.003 \\
\hline Quartile & December & & & & & & & & \\
\hline & Excluded & $(4,8)$ & 538 & 25.7 & 24.3 & 29.7 & 20.3 & 9.851 & 0.002 \\
\hline & & $(5,7)$ & & 27.0 & 23.0 & 26.6 & 23.4 & 2.714 & 0.099 \\
\hline & & $(6,6)$ & & 27.5 & 22.5 & 26.6 & 23.4 & 3.784 & 0.052 \\
\hline & & $(7,5)$ & & 28.3 & 21.7 & 26.8 & 23.2 & 5.896 & 0.015 \\
\hline & & $(8,4)$ & & 28.1 & 21.9 & 28.4 & 21.6 & 9.138 & 0.003 \\
\hline
\end{tabular}

Table 5

Data for the classifications is constructed on a yearly basis from monthly returns of 141 Global Equity Funds having a detailed objective of Global Growth, and aggregated for the sample period 1994 - 1997. Cell frequencies are reported for a $2 \times 2$ classification scheme involving the rank-ordered variables: (i) the Risk Adjustment Ratio $(R A R)$; and (ii) the compound total return through the first $M$ months of the year (RTN). Five different values are given for the interim assessment dates: $M=4,5,6,7$ and 8 . RAR is the ratio of the standard deviations measured before and after month $M$. Funds are divided into four groups on a yearly basis according to (i) whether RTN is below ("low" or "loser") or above ("high" or "winner") the median (Panel A) or in the highest ("winner") or lowest ("loser") quartile (Panel B), and (ii) whether $R A R$ is above ("high") or below ("low") the median. Included are results for $R A R$ rankings calculated both with and without December returns.

\footnotetext{
${ }^{4}$ The $\chi^{2}$ statistic is calculated based on the null hypothesis that each cell should receive an equal distribution (i.e., 25 percent) of the sample.
} 
Sample frequency (\% of Observations)

\begin{tabular}{|c|c|c|c|c|c|c|c|c|c|}
\hline \multirow[b]{2}{*}{ Ranking } & \multirow[b]{2}{*}{ Returns } & \multirow[b]{2}{*}{$\begin{array}{c}\text { Assessment } \\
\text { Period }\end{array}$} & \multirow[b]{2}{*}{ Observations } & \multicolumn{2}{|c|}{$\begin{array}{l}\text { Low RTN } \\
\text { ("Losers") }\end{array}$} & \multicolumn{2}{|c|}{$\begin{array}{l}\text { High } R T N \\
\text { ("Winners") }\end{array}$} & \multirow[b]{2}{*}{$\chi^{2}$} & \multirow[b]{2}{*}{$\begin{array}{c}\rho- \\
\text { value }^{5}\end{array}$} \\
\hline & & & & $\begin{array}{l}\text { "Low" } \\
R A R\end{array}$ & $\begin{array}{l}\text { "High" } \\
R A R\end{array}$ & $\begin{array}{l}\text { "Low" } \\
R A R\end{array}$ & $\begin{array}{l}\text { "High" } \\
R A R\end{array}$ & & \\
\hline \multirow[t]{5}{*}{ Median } & All Monthly & $(4,8)$ & 578 & 22.1 & 28.4 & 28.4 & 21.1 & $\begin{array}{l}10.65 \\
1\end{array}$ & 0.001 \\
\hline & & $(5,7)$ & & 25.3 & 25.3 & 25.3 & 24.2 & 0.187 & 0.666 \\
\hline & & $(6,6)$ & & 26.5 & 24.0 & 24.0 & 25.4 & 0.962 & 0.327 \\
\hline & & $(7,5)$ & & 26.3 & 24.2 & 24.2 & 25.3 & 0.685 & 0.408 \\
\hline & & $(8,4)$ & & 23.7 & 26.8 & 26.8 & 22.7 & 3.176 & 0.075 \\
\hline \multirow[t]{5}{*}{ Median } & $\begin{array}{l}\text { December } \\
\text { Excluded }\end{array}$ & $(4,8)$ & 578 & 21.8 & 28.7 & 28.7 & 20.8 & $\begin{array}{l}12.92 \\
0\end{array}$ & 0.000 \\
\hline & & $(5,7)$ & & 25.6 & 24.9 & 24.9 & 24.6 & 0.131 & 0.717 \\
\hline & & $(6,6)$ & & 26.6 & 23.9 & 23.9 & 25.6 & 1.294 & 0.255 \\
\hline & & $(7,5)$ & & 27.3 & 23.2 & 23.2 & 26.3 & 3.176 & 0.075 \\
\hline & & $(8,4)$ & & 24.4 & 26.1 & 26.1 & 23.4 & 1.294 & 0.255 \\
\hline \multirow[t]{5}{*}{ Quartile } & All Monthly & $(4,8)$ & 288 & 21.9 & 28.1 & 28.1 & 21.9 & 4.500 & 0.034 \\
\hline & & $(5,7)$ & & 22.9 & 27.1 & 26.1 & 24.0 & 1.250 & 0.264 \\
\hline & & $(6,6)$ & & 27.8 & 22.2 & 24.7 & 25.3 & 1.806 & 0.179 \\
\hline & & $(7,5)$ & & 26.4 & 23.6 & 25.3 & 24.7 & 0.472 & 0.492 \\
\hline & & $(8,4)$ & & 24.7 & 25.3 & 30.2 & 19.8 & 6.278 & 0.012 \\
\hline \multirow[t]{6}{*}{ Quartile } & December & & & & & & & & \\
\hline & Excluded & $(4,8)$ & 288 & 22.9 & 27.1 & 28.1 & 21.9 & 3.250 & 0.071 \\
\hline & & $(5,7)$ & & 26.7 & 23.3 & 24.3 & 25.7 & 0.806 & 0.369 \\
\hline & & $(6,6)$ & & 29.2 & 20.8 & 23.6 & 26.4 & 4.444 & 0.035 \\
\hline & & $(7,5)$ & & 27.4 & 22.6 & 25.3 & 24.7 & 1.389 & 0.239 \\
\hline & & $(8,4)$ & & 24.7 & 25.3 & 30.2 & 19.8 & 6.278 & 0.012 \\
\hline
\end{tabular}

Table 6

Data for the classifications is constructed on a yearly basis from monthly returns of 673 funds having a broad objective of International Equity, and aggregated for the sample period 1989 - 1997. Cell frequencies are reported for a 2 X 2 classification scheme involving the rank-ordered variables: (i) the Risk Adjustment Ratio $(R A R)$; and (ii) the compound total return through the first $M$ months of the year $(R T N)$. Five different values are given for the interim assessment dates: $M=4,5,6,7$ and $8 . R A R$ is the ratio of the standard deviations measured before and after month $M$. Funds are divided into four groups on a yearly basis according to (i) whether $R T N$ is below ("low" or "loser") or above ("high" or "winner") the median or in the highest ("winner") or lowest ("loser") quartile, and (ii) whether $R A R$ is above ("high") or below ("low") the median. Included are results for RAR rankings calculated both with and without December returns.

\footnotetext{
${ }^{5}$ The $\chi^{2}$ statistic is calculated based on the null hypothesis that each cell should receive an equal distribution (i.e., 25 percent) of the sample.
} 


\begin{tabular}{|c|c|c|c|c|c|c|c|c|c|}
\hline \multirow[b]{2}{*}{ Ranking } & \multirow[b]{2}{*}{ Returns } & \multirow[b]{2}{*}{$\begin{array}{l}\text { Assessment } \\
\text { Period }\end{array}$} & \multirow[b]{2}{*}{ Observations } & \multicolumn{2}{|c|}{$\begin{array}{l}\text { Low } R T N \\
\text { ("Losers") }\end{array}$} & \multicolumn{2}{|c|}{$\begin{array}{c}\text { High } R T N \\
\text { ("Winners") }\end{array}$} & \multirow[b]{2}{*}{$x^{2}$} & \multirow[b]{2}{*}{$\rho$-value ${ }^{6}$} \\
\hline & & & & $\begin{array}{l}\text { "Low" } \\
\text { RAR }\end{array}$ & $\begin{array}{l}\text { "High" } \\
\text { RAR }\end{array}$ & $\begin{array}{l}\text { "Low" } \\
\text { RAR }\end{array}$ & $\begin{array}{l}\text { "High" } \\
\text { RAR }\end{array}$ & & \\
\hline \multirow[t]{5}{*}{ Median } & $\begin{array}{c}\text { All } \\
\text { Monthly }\end{array}$ & $(4,8)$ & 2347 & 25.3 & 24.8 & 24.8 & 25.1 & 0.175 & 0.676 \\
\hline & & $(5,7)$ & & 25.4 & 24.7 & 24.7 & 25.2 & 0.332 & 0.565 \\
\hline & & $(6,6)$ & & 25.9 & 24.2 & 24.2 & 25.6 & 2.190 & 0.139 \\
\hline & & $(7,5)$ & & 24.5 & 25.6 & 25.6 & 24.2 & 1.627 & 0.202 \\
\hline & & $(8,4)$ & & 21.9 & 28.2 & 28.2 & 21.7 & $\begin{array}{l}38.62 \\
4\end{array}$ & 0.000 \\
\hline \multirow[t]{6}{*}{ Median } & December & & & & & & & & \\
\hline & Excluded & $(4,8)$ & 2347 & 25.8 & 24.3 & 24.3 & 25.6 & 1.934 & 0.164 \\
\hline & & $(5,7)$ & & 25.4 & 24.7 & 24.7 & 25.2 & 0.332 & 0.565 \\
\hline & & $(6,6)$ & & 25.4 & 24.8 & 24.8 & 25.1 & 0.267 & 0.605 \\
\hline & & $(7,5)$ & & 24.7 & 25.4 & 25.4 & 24.5 & 0.605 & 0.437 \\
\hline & & $(8,4)$ & & 22.0 & 28.1 & 28.1 & 21.8 & $\begin{array}{l}36.34 \\
3\end{array}$ & 0.000 \\
\hline \multirow[t]{5}{*}{ Quartile } & $\begin{array}{c}\text { All } \\
\text { Monthly }\end{array}$ & $(4,8)$ & 1174 & 26.7 & 23.3 & 26.1 & 23.9 & 3.656 & 0.056 \\
\hline & & $(5,7)$ & & 26.6 & 23.4 & 25.9 & 24.1 & 3.083 & 0.079 \\
\hline & & $(6,6)$ & & 27.2 & 22.8 & 26.1 & 23.9 & 5.496 & 0.019 \\
\hline & & $(7,5)$ & & 25.0 & 25.0 & 26.8 & 23.2 & 3.152 & 0.076 \\
\hline & & $(8,4)$ & & 22.1 & 27.9 & 32.5 & 17.5 & $\begin{array}{l}61.48 \\
2\end{array}$ & 0.000 \\
\hline \multirow[t]{6}{*}{ Quartile } & December & & & & & & & & \\
\hline & Excluded & $(4,8)$ & 1174 & 27.5 & 22.5 & 25.6 & 24.4 & 6.313 & 0.012 \\
\hline & & $(5,7)$ & & 26.7 & 23.3 & 26.7 & 23.3 & 5.182 & 0.023 \\
\hline & & $(6,6)$ & & 26.7 & 23.3 & 26.9 & 23.1 & 6.041 & 0.014 \\
\hline & & $(7,5)$ & & 25.2 & 24.8 & 26.7 & 23.3 & 2.634 & 0.105 \\
\hline & & $(8,4)$ & & 22.1 & 27.9 & 32.2 & 17.8 & $\begin{array}{l}56.76 \\
7\end{array}$ & 0.000 \\
\hline
\end{tabular}

Table 7

Data for the classifications is constructed on a yearly basis from monthly returns of 232 International Equity Funds having a detailed objective of International Growth, and aggregated for the sample period 1989 - 1997. Cell frequencies are reported for a 2 X 2 classification scheme involving the rank-ordered variables: (i) the Risk Adjustment Ratio $(R A R)$; and (ii) the compound total return through the first $M$ months of the year $(R T N)$. Five different values are given for the interim assessment dates: $M=4,5,6,7$ and 8. RAR is the ratio of the standard deviations measured before and after month $M$. Funds are divided into four groups on a yearly basis according to (i) whether $R T N$ is below ("low" or "loser") or above ("high" or "winner") the median or in the highest ("winner") or lowest ("loser") quartile, and (ii) whether RAR is above ("high") or below ("low") the median. Included are results for $R A R$ rankings calculated both with and without December returns.

\footnotetext{
${ }^{6}$ The $\chi^{2}$ statistic is calculated based on the null hypothesis that each cell should receive an equal distribution (i.e., 25 percent) of the sample.
} 
Sample frequency (\% of Observations)

\begin{tabular}{|c|c|c|c|c|c|c|c|c|c|}
\hline \multirow[b]{2}{*}{ Ranking } & \multirow[b]{2}{*}{ Returns } & \multirow[b]{2}{*}{$\begin{array}{c}\text { Assessment } \\
\text { Period } \\
\end{array}$} & \multirow[b]{2}{*}{ Observations } & \multicolumn{2}{|c|}{$\begin{array}{l}\text { Low RTN } \\
\text { ("Losers") }\end{array}$} & \multicolumn{2}{|c|}{$\begin{array}{c}\text { High } R T N \\
\text { ("Winners") }\end{array}$} & \multirow[b]{2}{*}{$\chi^{2}$} & \multirow[b]{2}{*}{$\rho$-value ${ }^{7}$} \\
\hline & & & & $\begin{array}{l}\text { "Low" } \\
\text { RAR }\end{array}$ & $\begin{array}{l}\text { "High" } \\
\text { RAR }\end{array}$ & $\begin{array}{l}\text { "Low" } \\
\text { RAR }\end{array}$ & $\begin{array}{l}\text { "High" } \\
\text { RAR }\end{array}$ & & \\
\hline \multirow[t]{5}{*}{ Median } & $\begin{array}{c}\text { All } \\
\text { Monthly }\end{array}$ & $(4,8)$ & 895 & 25.9 & 24.2 & 24.2 & 25.6 & 0.835 & 0.361 \\
\hline & & $(5,7)$ & & 26.4 & 23.8 & 23.8 & 26.0 & 2.086 & 0.149 \\
\hline & & $(6,6)$ & & 26.9 & 23.2 & 23.2 & 26.6 & 4.455 & 0.035 \\
\hline & & $(7,5)$ & & 26.3 & 23.9 & 23.9 & 25.9 & 1.720 & 0.190 \\
\hline & & $(8,4)$ & & 24.6 & 25.6 & 25.6 & 24.2 & 0.513 & 0.474 \\
\hline \multirow[t]{6}{*}{ Median } & December & & & & & & & & \\
\hline & Excluded & $(4,8)$ & 895 & 26.6 & 23.6 & 23.6 & 26.3 & 2.926 & 0.087 \\
\hline & & $(5,7)$ & & 27.2 & 23.0 & 23.0 & 26.8 & 5.653 & 0.017 \\
\hline & & $(6,6)$ & & 26.6 & 23.6 & 23.6 & 26.3 & 2.926 & 0.087 \\
\hline & & $(7,5)$ & & 26.5 & 23.7 & 23.7 & 26.1 & 2.488 & 0.115 \\
\hline & & $(8,4)$ & & 24.9 & 25.3 & 25.3 & 24.6 & 0.111 & 0.739 \\
\hline \multirow[t]{5}{*}{ Quartile } & All & $(4,8)$ & 446 & 27.1 & 22.9 & 24.9 & 25.1 & 1.623 & 0.203 \\
\hline & & $(5,7)$ & & 29.6 & 20.4 & 24.0 & 26.0 & 7.901 & 0.005 \\
\hline & & $(6,6)$ & & 28.5 & 21.5 & 22.6 & 27.4 & 6.287 & 0.012 \\
\hline & & $(7,5)$ & & 27.4 & 22.6 & 22.9 & 27.1 & 3.596 & 0.058 \\
\hline & & $(8,4)$ & & 26.7 & 23.3 & 27.8 & 22.2 & 3.812 & 0.051 \\
\hline \multirow[t]{6}{*}{ Quartile } & December & & & & & & & & \\
\hline & Excluded & $(4,8)$ & 446 & 27.8 & 22.2 & 24.4 & 25.6 & 2.915 & 0.088 \\
\hline & & $(5,7)$ & & 31.2 & 18.8 & 22.9 & 27.1 & $\begin{array}{l}15.18 \\
4\end{array}$ & 0.000 \\
\hline & & $(6,6)$ & & 28.0 & 22.0 & 24.0 & 26.0 & 3.632 & 0.057 \\
\hline & & $(7,5)$ & & 26.9 & 23.1 & 22.9 & 27.1 & 2.915 & 0.088 \\
\hline & & $(8,4)$ & & 26.7 & 23.3 & 28.3 & 21.7 & 4.780 & 0.029 \\
\hline
\end{tabular}

Table 8

Comparative Frequency Distribution for tests: (1) New versus Entrenched Funds based on Fund Life. "Entrenched" funds are defined as those in existence prior to the median existence for a particular tournament year. "New" funds enter after the median existence for a particular tournament year. (2) Small versus Large Funds based on Fund Size. "Large" funds are defined as those having a greater number of total assets than the median number of total assets for a particular tournament year. "Small" funds have a smaller number of total assets than the median number of total assets for a particular tournament year. (3) New versus Entrenched Funds based on Manager Life. "Entrenched" funds are defined as those having the same manager(s) prior to the median existence for a particular tournament year. "New" funds have hired manager(s) after the median existence for a particular tournament year. (4) Funds with Large year-end Cash Flow versus Funds with Small year-end Cash Flow. "Large" funds are defined as those funds having larger cash flows relative to total net assets than the median cash flows relative to total net assets for a particular tournament year. "Small" funds are defined as those funds having smaller cash flows relative to total net assets than the median cash flows relative to total net assets for a particular tournament year.

\footnotetext{
${ }^{7}$ The $\chi^{2}$ statistic is calculated based on the null hypothesis that each cell should receive an equal distribution (i.e., 25 percent) of the sample.
} 


\begin{tabular}{|c|c|c|c|c|c|c|c|c|}
\hline \multirow{3}{*}{ Test } & \multirow[b]{3}{*}{$\begin{array}{c}\text { Broad Objective } \\
\text { Detailed } \\
\text { Objective } \\
\text { (Period ) }\end{array}$} & \multirow[b]{3}{*}{ Sample (\# of Obs.) } & \multicolumn{6}{|c|}{ Sample frequency ( $\%$ of Observations) } \\
\hline & & & \multicolumn{2}{|c|}{$\begin{array}{l}\text { Low } R T N \\
\text { ("Losers") }\end{array}$} & \multicolumn{2}{|c|}{$\begin{array}{c}\text { High RTN } \\
\text { ("Winners") }\end{array}$} & \multirow[b]{2}{*}{$\chi^{2}$} & \multirow[b]{2}{*}{$\rho$-value } \\
\hline & & & $\begin{array}{c}\text { "Low } \\
" \\
R A R\end{array}$ & $\begin{array}{l}\text { "High" } \\
R A R\end{array}$ & $\begin{array}{l}\text { "Low } \\
" \\
R A R\end{array}$ & $\begin{array}{l}\text { "High" } \\
R A R\end{array}$ & & \\
\hline $\begin{array}{l}\text { (1a) New vs. } \\
\text { Entrenched } \\
\text { based on Fund } \\
\text { Life }\end{array}$ & $\begin{array}{c}\text { Global Equity } \\
\text { Global Growth } \\
(1989-1997)\end{array}$ & $\begin{array}{c}\text { Entrenched }(n=365) \\
\quad \text { New }(n=213)\end{array}$ & $\begin{array}{l}24.4 \\
24.4\end{array}$ & $\begin{array}{l}24.9 \\
24.4\end{array}$ & $\begin{array}{l}24.9 \\
24.4\end{array}$ & $\begin{array}{l}25.8 \\
26.8\end{array}$ & $\begin{array}{l}0.140 \\
0.352\end{array}$ & $\begin{array}{l}0.709 \\
0.553\end{array}$ \\
\hline $\begin{array}{l}\text { (1b) New vs. } \\
\text { Entrenched } \\
\text { based on Fund } \\
\text { Life }\end{array}$ & $\begin{array}{l}\text { Int'l Equity } \\
\text { Int'l Growth } \\
(1989-1997)\end{array}$ & $\begin{array}{c}\text { Entrenched }(n=489) \\
\text { New }(n=406)\end{array}$ & $\begin{array}{l}27.0 \\
24.6\end{array}$ & $\begin{array}{l}22.9 \\
24.9\end{array}$ & $\begin{array}{l}22.9 \\
24.9\end{array}$ & $\begin{array}{l}27.2 \\
25.6\end{array}$ & $\begin{array}{l}3.442 \\
0.089\end{array}$ & $\begin{array}{l}0.064 \\
0.766\end{array}$ \\
\hline $\begin{array}{l}\text { (2a) Small vs. } \\
\text { Large based on } \\
\text { Fund Size }\end{array}$ & $\begin{array}{c}\text { Global Equity } \\
\text { Global Growth } \\
(1989-1997)\end{array}$ & $\begin{array}{l}\text { Large }(n=287) \\
\text { Small }(n=250)\end{array}$ & $\begin{array}{l}25.8 \\
25.2\end{array}$ & $\begin{array}{l}23.7 \\
24.0\end{array}$ & $\begin{array}{l}23.7 \\
23.2\end{array}$ & $\begin{array}{l}26.8 \\
27.6\end{array}$ & $\begin{array}{l}0.847 \\
1.104\end{array}$ & $\begin{array}{l}0.358 \\
0.293\end{array}$ \\
\hline $\begin{array}{l}\text { (2b) Small vs. } \\
\text { Large based on } \\
\text { Fund Size }\end{array}$ & $\begin{array}{l}\text { Int'l Equity } \\
\text { Int'1 Growth } \\
(1989-1997)\end{array}$ & $\begin{array}{l}\text { Large }(n=447) \\
\text { Small }(n=448)\end{array}$ & $\begin{array}{l}23.7 \\
28.8\end{array}$ & $\begin{array}{l}26.2 \\
20.8\end{array}$ & $\begin{array}{l}26.2 \\
20.8\end{array}$ & $\begin{array}{l}23.9 \\
29.7\end{array}$ & $\begin{array}{c}0.991 \\
12.964\end{array}$ & $\begin{array}{l}0.320 \\
0.000\end{array}$ \\
\hline $\begin{array}{l}\text { (3a) New vs. } \\
\text { Entrenched } \\
\text { based on } \\
\text { Manager Life }\end{array}$ & $\begin{array}{c}\text { Global Equity } \\
\text { Global Growth } \\
(1989-1997)\end{array}$ & $\begin{array}{l}\text { Entrenched }(n=281) \\
\text { New }(n=296)\end{array}$ & $\begin{array}{l}21.4 \\
26.7\end{array}$ & $\begin{array}{l}27.8 \\
23.0\end{array}$ & $\begin{array}{l}27.8 \\
23.0\end{array}$ & $\begin{array}{l}23.1 \\
27.4\end{array}$ & $\begin{array}{l}3.598 \\
1.973\end{array}$ & $\begin{array}{l}0.058 \\
0.160\end{array}$ \\
\hline $\begin{array}{l}\text { (3b) New vs. } \\
\text { Entrenched } \\
\text { based on } \\
\text { Manager Life }\end{array}$ & $\begin{array}{l}\text { Int'l Equity } \\
\text { Int'l Growth } \\
(1989-1997)\end{array}$ & $\begin{array}{l}\text { Entrenched }(n=448) \\
\quad \text { New }(n=447)\end{array}$ & $\begin{array}{l}26.8 \\
25.7\end{array}$ & $\begin{array}{l}23.0 \\
23.9\end{array}$ & $\begin{array}{l}23.0 \\
24.2\end{array}$ & $\begin{array}{l}27.2 \\
26.2\end{array}$ & $\begin{array}{l}2.911 \\
0.669\end{array}$ & $\begin{array}{l}0.088 \\
0.413\end{array}$ \\
\hline $\begin{array}{l}\text { (4a) Large year- } \\
\text { end Cash Flow } \\
\text { versus Small } \\
\text { year -end Cash } \\
\text { Flow }\end{array}$ & $\begin{array}{c}\text { Global Equity } \\
\text { Global Growth } \\
(1990-1997)\end{array}$ & $\begin{array}{l}\text { Large }(n=265) \\
\text { Small }(n=270)\end{array}$ & $\begin{array}{l}25.7 \\
23.5\end{array}$ & $\begin{array}{l}23.8 \\
25.9\end{array}$ & $\begin{array}{l}23.8 \\
25.9\end{array}$ & $\begin{array}{l}26.8 \\
24.4\end{array}$ & $\begin{array}{l}0.706 \\
0.400\end{array}$ & $\begin{array}{l}0.401 \\
0.527\end{array}$ \\
\hline $\begin{array}{l}\text { (4b) Large year- } \\
\text { end Cash Flow } \\
\text { versus Small } \\
\text { year -end Cash } \\
\text { Flow }\end{array}$ & $\begin{array}{l}\text { Int'l Equity } \\
\text { Int'l Growth } \\
(1990-1997)\end{array}$ & $\begin{array}{c}\text { Large }(n=445) \\
\text { Small }(n=426)\end{array}$ & $\begin{array}{l}23.8 \\
26.1\end{array}$ & $\begin{array}{l}25.8 \\
23.5\end{array}$ & $\begin{array}{l}25.8 \\
23.5\end{array}$ & $\begin{array}{l}24.5 \\
27.0\end{array}$ & $\begin{array}{l}0.546 \\
1.662\end{array}$ & $\begin{array}{l}0.460 \\
0.197\end{array}$ \\
\hline
\end{tabular}

\section{Table 9}

OLS model using the Risk Adjustment Ratio (RAR) for assessment period $(5,7) .{ }^{9}$ Results are presented using both median (1a, 2a, 3a \& 4a) and quartile rankings (1b, 2b, 3b \& 4b), as defined by RTN, in addition to the inclusion of all monthly returns (1a through $2 \mathrm{~b}$ ) and the exclusion of December returns (3a through $4 \mathrm{~b}$ ).

(t-stats in parentheses)

\footnotetext{
${ }^{8}$ The $\chi^{2}$ statistic is calculated based on the null hypothesis that each cell should receive an equal distribution (i.e., 25 percent) of the sample.

${ }^{9}$ Following the rationale used by BHS.
} 


\begin{tabular}{|c|c|c|c|c|c|c|c|c|}
\hline & $\begin{array}{c}\text { Regression } \\
\text { (1a) }\end{array}$ & $\begin{array}{c}\text { Regression } \\
\text { (1b) }\end{array}$ & $\begin{array}{c}\text { Regression } \\
(2 a)\end{array}$ & $\begin{array}{c}\text { Regression } \\
(2 \mathrm{~b})\end{array}$ & $\begin{array}{c}\text { Regression } \\
\text { (3a) }\end{array}$ & $\begin{array}{c}\text { Regression } \\
(3 \mathrm{~b})\end{array}$ & $\begin{array}{c}\text { Regression } \\
\quad(4 a)\end{array}$ & $\begin{array}{c}\text { Regression } \\
(4 \mathrm{~b})\end{array}$ \\
\hline Intercept & $\begin{array}{c}1.7669 \\
(30.8416)\end{array}$ & $\begin{array}{c}1.7376 \\
(26.1950)\end{array}$ & $\begin{array}{c}1.8964 \\
(21.4101)\end{array}$ & $\begin{array}{c}1.8360 \\
(15.8462)\end{array}$ & $\begin{array}{c}1.1935 \\
(32.2712)\end{array}$ & $\begin{array}{c}1.8752 \\
(27.3103)\end{array}$ & $\begin{array}{c}2.0609 \\
(22.4985)\end{array}$ & $\begin{array}{c}1.9967 \\
(16.6643)\end{array}$ \\
\hline LOSE/WIN & $\begin{array}{c}-0.0323 \\
(-0.6809)\end{array}$ & $\begin{array}{c}0.0155 \\
(0.2841)\end{array}$ & $\begin{array}{c}-0.0942 \\
(-0.9181)\end{array}$ & $\begin{array}{c}0.0227 \\
(0.1907)\end{array}$ & $\begin{array}{c}-0.0400 \\
(-0.8155)\end{array}$ & $\begin{array}{c}0.0220 \\
(0.3889)\end{array}$ & $\begin{array}{c}-0.1074 \\
(-1.0113)\end{array}$ & $\begin{array}{c}0.0192 \\
(0.1564)\end{array}$ \\
\hline \multirow{2}{*}{$\begin{array}{l}\text { GLOBINTL } \\
\text { FUNDLIFE }\end{array}$} & $\begin{array}{c}0.1883 \\
(3.8954)\end{array}$ & $\begin{array}{c}0.1882 \\
(3.8909)\end{array}$ & $\begin{array}{c}0.1101 \\
(0.9688)\end{array}$ & $\begin{array}{c}0.0142 \\
(0.1071)\end{array}$ & $\begin{array}{c}0.1997 \\
(3.9893)\end{array}$ & $\begin{array}{c}0.1994 \\
(3.9837)\end{array}$ & $\begin{array}{c}0.0992 \\
(0.8447)\end{array}$ & $\begin{array}{c}-0.0033 \\
(-0.0244)\end{array}$ \\
\hline & $\begin{array}{c}-0.3457 \\
(-6.3736)\end{array}$ & $\begin{array}{c}-0.3473 \\
(-3.6984)\end{array}$ & $\begin{array}{c}-0.5618 \\
(-5.2903)\end{array}$ & $\begin{array}{c}-0.4692 \\
(-3.5191)\end{array}$ & $\begin{array}{c}-0.4667 \\
(-8.3133)\end{array}$ & $\begin{array}{c}-0.4688 \\
(-8.3443)\end{array}$ & $\begin{array}{c}-0.7021 \\
(-6.3932)\end{array}$ & $\begin{array}{c}-0.6190 \\
(-4.4890)\end{array}$ \\
\hline FUNDSIZE & $\begin{array}{c}0.0001 \\
(4.6510)\end{array}$ & $\begin{array}{c}0.0001 \\
(4.7405)\end{array}$ & $\begin{array}{c}0.0001 \\
(4.6905)\end{array}$ & $\begin{array}{c}0.0001 \\
(4.7749)\end{array}$ & $\begin{array}{c}0.0001 \\
(5.2473)\end{array}$ & $\begin{array}{c}0.0001 \\
(5.3549)\end{array}$ & $\begin{array}{c}0.0001 \\
(5.3050)\end{array}$ & $\begin{array}{c}0.0001 \\
(5.4146)\end{array}$ \\
\hline MGRTENURE & $\begin{array}{c}-0.0530 \\
(-1.0589)\end{array}$ & $\begin{array}{c}-0.0496 \\
(-0.9896)\end{array}$ & $\begin{array}{c}-0.2094 \\
(-1.9222)\end{array}$ & $\begin{array}{c}-0.2171 \\
(-1.6271)\end{array}$ & $\begin{array}{c}-0.0560 \\
(-1.0804)\end{array}$ & $\begin{array}{l}-0.0515 \\
(0.9937)\end{array}$ & $\begin{array}{c}-0.2393 \\
(-2.1421)\end{array}$ & $\begin{array}{c}-0.2434 \\
(-1.7643)\end{array}$ \\
\hline CASHFLOW & $\begin{array}{c}0.0008 \\
(2.7466)\end{array}$ & $\begin{array}{c}0.0008 \\
(2.7425)\end{array}$ & $\begin{array}{c}0.0008 \\
(2.6633)\end{array}$ & $\begin{array}{c}0.0008 \\
(2.6762)\end{array}$ & $\begin{array}{c}0.0007 \\
(2.1153)\end{array}$ & $\begin{array}{c}0.0007 \\
(2.1107)\end{array}$ & $\begin{array}{c}0.0006 \\
(2.0351)\end{array}$ & $\begin{array}{c}0.0007 \\
(2.0439)\end{array}$ \\
\hline LW/GI & & & $\begin{array}{c}0.0361 \\
(0.3724)\end{array}$ & $\begin{array}{c}0.1635 \\
(1.4600)\end{array}$ & & & $\begin{array}{c}0.0558 \\
(0.5562)\end{array}$ & $\begin{array}{c}0.1872 \\
(1.6162)\end{array}$ \\
\hline LW/FUNDLIFE & & & $\begin{array}{c}0.1716 \\
(1.5870)\end{array}$ & $\begin{array}{c}-0.0116 \\
(-0.0908)\end{array}$ & & & $\begin{array}{c}0.1841 \\
(1.6457)\end{array}$ & $\begin{array}{c}0.0072 \\
(0.0546)\end{array}$ \\
\hline LW/TENURE & & & $\begin{array}{c}-0.1004 \\
(-0.9962)\end{array}$ & $\begin{array}{c}-0.0808 \\
(-0.6523)\end{array}$ & & & $\begin{array}{c}-0.1152 \\
(-1.1054)\end{array}$ & $\begin{array}{c}-0.0982 \\
(-0.7664)\end{array}$ \\
\hline GI/FUNDLIFE & & & $\begin{array}{c}-0.0515 \\
(-0.4384)\end{array}$ & $\begin{array}{c}-0.0600 \\
(-0.5092)\end{array}$ & & & $\begin{array}{c}-0.0737 \\
(-0.6067)\end{array}$ & $\begin{array}{c}-0.0838 \\
(-0.6883)\end{array}$ \\
\hline GI/TENURE & & & $\begin{array}{c}0.1256 \\
(1.1691)\end{array}$ & $\begin{array}{c}0.1259 \\
(1.1726)\end{array}$ & & & $\begin{array}{c}0.1677 \\
(1.5095)\end{array}$ & $\begin{array}{c}0.1683 \\
(1.5151)\end{array}$ \\
\hline LIFE/TENURE & & & $\begin{array}{c}0.2575 \\
(2.3416)\end{array}$ & $\begin{array}{c}0.2727 \\
(2.4758)\end{array}$ & & & $\begin{array}{c}0.2893 \\
(2.5450)\end{array}$ & $\begin{array}{c}0.3084 \\
(2.7076)\end{array}$ \\
\hline
\end{tabular}


Notes 